\title{
Influence of Demographic Variable on Job Satisfaction Among Academicians in Public Universities
}

\author{
Oladipo Kolapo Sakiru, Ismi Arif Bin Ismail, Bahaman Abu Samah, Adekanye Temitope Busayo \\ Universiti Putra Malaysia, Serdang, Selangor, Malaysia
}

\begin{abstract}
Fundamental point in this study is to decide the relationship between demographic variables (age, sex and educational qualification) and academician's job satisfaction in Nigerian public universities. Quantitative study is being used in this research, wherein a total of 199 academicians from Nigerian public universities studying in three researches Malaysia universities are the data for the present study. Simple random sampling method is being utilized to select the academicians in the universities. The outcomes uncovered that there was no significant difference between academician's job satisfaction and the demographic variables tested in this study (age, educational qualifications and gender). It could be recommended that the academics in public universities in Nigeria should be compensated adequately, as well as opportunities and financial support should be given to secure higher educational qualifications. Further study, can be utilized to further improve the critical of demographic variable in job satisfaction of the academicians in Nigerian public universities.
\end{abstract}

\section{Introduction}

The relevance of university education to the economic, industrial and technological development of Nigeria and other countries of the world cannot be overemphasized. Higher education institutions in recent times are viewed as agents of social change and development. They are role models of innovation and change and they are expected to play a critical role in promoting sustainable economic, social and cultural development. They are the major drivers of economic knowledge-driven global economy. Thus, the universities as higher institutions are established to accomplish specified objectives. The Federal Republic of Nigeria (FRN) articulates the objectives of higher education to include the contribution to national development through relevant manpower training, the acquisition, development and inculcation of proper values for the development of intellectual capability of individuals to understand and appreciate the local and external environments.

A fulfilled and upbeat staff is needed in the workforce of an association to have the capacity to accomplish her objectives and goals [40]. Essentially is the fact that for any universities to take off and accomplish its vital objectives would firmly rely on upon her ability to pull in, hold and keep up able and fulfilled staff in its occupation. The universities being an establishment of higher learning that gives labor needs to propel national advancement through both the general population and private division must itself be equipped for guaranteeing sufficient labor arranging and improvement she could hence not bear to disregard need and the essentials of work-force fulfillment.

Lecturers are the heart of educational organizations in which all instructional procedure focuses on. They are key players in the training framework. They likewise assume basic parts in progressing economic and innovative advancement through teaching and educating human resources [5]. To accomplish instructive objectives, lecturers can outline and plan educational programs, perform instructing - learning exercises furthermore have cooperation in scholastics studies, are a part of academic and community service activities, preserve a high level of institutional standards and be active in strategies teaching - learning with students in the classroom.

One might begin by asking if there are any institutional factors which more or less cause certain categories of lecturers to demonstrate a poor attitude to work and others a positive one. One such factor may not be too far from the type of leadership that exists in the school [42]. Leadership is one of the basic and most important needs of each organization. It is often considered as the solution to most organizational problems. It can direct human resources toward the strategic objectives of the organization and ensure that organizational functions are aligned with the external environment. Moreover, effective leaders are able to predict the future probabilities and design choice strategies to satisfy uncertainties. They can lead organizations to success 
by paying more attention to environmental changes, which in turn helps them set proper goals and objectives. One of the essential factors contributing to leadership effectiveness is the style of a leader. It is among the important components of a leader's leadership situation [21], which can cause success in organizations.

Lecturers are relied upon to give proficient meetings, distribute their discoveries, and behavior scholastic examination, so that the group could advantage, gives addresses and be focused on the objectives, qualities, vision and mission of the tertiary foundations in Nigeria. To do this, lecturers needs to stay aware of new advances, new procedures and new information with a specific end goal to give the understudies the best [5]. It was demonstrated that the issues of staying longer and performing better occupation in the organization employees who are profoundly fulfilled better.

Numerous studies on components that influenced job satisfaction have been finished. Among the elements is occupation self-governance, working environment and leadership styles. Jafar, comprehensively sorted the components into work and business related variables. Because of its significance, numerous explorations relating to job satisfaction in different professions have been done, for example, the construction, library, [22] and education [10]. There is a shortage of exploration on the subject enthusiasm for Nigeria, critically in connection to the demographic variable and academicians job satisfaction, subsequently, why this study is viewed as important as of this time.

This study thus aims to investigate the relationship between the demographic variables and job satisfaction among academicians in Nigerian public universities. The specific objectives are to examine: (a) the differences between job satisfactions of the academicians based on gender, (b) the differences between job satisfactions of the academicians based on age, and (c) the differences between job satisfactions of the academicians based on educational level.

\section{Background}

\subsection{The role of lecturers in universities}

Lecturers are the heart of educational institutions in which all instructional process concentrates on. They are key players in the education system. They also play critical roles in advancing economic and technological development through educating human resources [5]. To achieve educational goals, lecturers can design and formulate curriculum, perform teaching -learning activities and also have interaction in acedemics studies, be a part of academic and community service activities, preserve a high level of institutional standards and be active in teaching learning strategies in the classroom with students.

Lecturers not only have to give lecturer, they are also expected to provide professional consultations, conduct academic research, publish their findings so that the community could benefit and be committed to the goals, values,vision and mission of the tertiary institutions in Nigeria. To do this, they also need to keep up with new knowledge; new technologies and new techniques in order deliver the best to their students [5]. In addition, studies have shown that employees who are highly satisfied will stay longer and perform their job better.

However, School leaders need to provide inschool working conditions in which lectures could grow professionally, and create a work environment that could sustain lecturer's job satisfaction [14] [50] argued that working conditions affect the degree to which lecturers are actively committed to and engaged in lecturing. Thus, to guarantee that the lecturers are able and willing to carry out their tasks successfully, administrators well as the management needs to know and understand the factor that affects lecturers job satisfaction and subsequently shed some light on the job satisfaction level.

\subsection{Importance of job satisfaction in higher learning institutions}

As the public university in Nigeria are moving towards a refined university there is a need to improve the lecturer's job satisfaction for the objectives to be met. In order to be successful in a global environment, public universities have to continually upgrade the skills and knowledge of their employees and use the latest ideas, an organization has to stay ahead of the latest development in human resource development [5]. University's employee are human beings and they are not factors of production, leading them and /or inspiring them requires "people -skills" as well as to connect emotionally and intellectually at the same time. It became increasing clear that people are our greatest assets and economic future rate more and more on the quality of the workforce.

The challenges of Nigerian public universities are to train, develop and empower a new generation of employees as well as re-equip existing employee with the mindset, skills and tools that will help them to facilitate the emergence of employee who can continually perform at a standard university. This is in line with the government objectives to enable the nation education to achieve a standard university meeting this expectation is longtime objectives. 
Therefore, Nigerian public universities need to emphasize the significance of their staff satisfaction first, to ensure that the objectives are met.

\subsection{Overview of job satisfaction}

Job satisfaction seems, by all accounts, to be what most laborers ache for and work towards in their different tries. It is a key to corporate achievement and a subject of talk in work and organizational writing. One of the routines used to build up and keep up a sound organizational structure is job satisfaction [1]. These days, it is believed that employees are vital resources in the organization, emphatically craving job satisfaction of their workers [42]. Nonappearance of job satisfaction fulfillment frequently prompts specialist's dormancy and lessened employee's duty. A great part of the mind channel in large portions of the employee has been credited to employment disappointment. Minimal ponder then, while Olowokere, emphasized that employment disappointment is an incredible indicator of stopping occupations. Adeyemo, considered the general movement of employees from one occupation to the next for greener field because their present state of work has an aftereffect of poor state of administration. Diaz-Serrano \& Cabral, confirmed this declaration as they considered job satisfaction as number indicator of expectations of general individual prosperity and in addition indicator to leave an occupation [27]. Job satisfaction has been portrayed in different courses by distinctive researchers. It was seen as a satisfaction procured with experience of different occupation exercises and prizes, and it likewise said it is the inclination in regard to, or viable reactions to parts of the work circumstance, it was additionally upheld that job satisfaction is a singular's general state of mind of employee towards his or her employment, [45].

\subsection{Job Satisfaction among Educators}

Lecturing is among the professions that need high commitment, the workload is heavy, the function is broad and also the lecturers are directly responsible in educating and shaping the students. Without satisfaction, some might even withdraw from the profession. Others who don't withdraw, but no more feel pleased with their job would most likely shirk within their daily responsibilities. These certainly result in other negative effects, especially towards the students. Chimanikire, discovered that the majority of the academic staff in tertiary institutions in Zimbabwe is not contented with their job. It was because of high volume of workload, and insufficient salaries, considerations and financial loans to facilitate the purchasing of houses and cars.

On the similar note, [4] who carried out a study on job satisfaction among lecturers in colleges of education in Southern Nigeria, discovered that generally, lecturers weren't pleased with their job. The participants indicated that they're pleased with their workload but highly dissatisfied their salary. In addition, the outcomes also demonstrated that there is a substantial negative relationship between age, education level and academic rank with job satisfaction.

Santhapparaj and Alam, examined the connection between pay, promotion, fringe benefit, Condition, support of research, support training, and gender with job satisfaction among the Academic employees in private colleges in Malaysia. The end result demonstrated that pay, promotion, condition and support of research considerably and positively associated with job satisfaction. Narimawati, analyzed the influence of labor satisfaction, business commitment and turnover intentions towards performances among lecturers in West Java's private greater education institutions. The outcomes demonstrated that job satisfaction, business commitment and turnover intention concurrently and partly have a significant effect on performance.

A report by [9] on job satisfaction and morale among American teachers identified more administrative support and leadership, better intergroup relations, positive school atmosphere and teachers' autonomy, as working conditions associated with higher teacher satisfaction and morale. Odanye, reported that favorable workplace environments were positively related to workers' job satisfaction regardless of workers' background characteristics or organizational demographics. Other scholars like, Adedeji, and Olaoye, submit that teachers in any school setting, who receive a great deal of parental and organizational support, are more satisfied than Teachers who do not. The authors reported a strong relationship among leadership styles of head teacher teachers` job satisfaction. Suzanne, Claudius, and Patricia, reported that interpersonal relationship, labor-management relations, motivation, workers training and development account for thirty three percent of the total variance, which is a very high variance, in the determination of workers ' morale and efficiency at workplace.

However, Babajide, P.B. and Ajala, report that the leadership style and communication climate in the organization has significantly influenced workers' morale. In essence, the level of Workers' participation and involvement in making decisions that affect organizational interest tend to influence their morale. This implies that, knowledge and level 
of awareness of workers on issues and problems affecting organization where they have invested their talents and skills could also affect their morale, job satisfaction, and intention to stay or quit an organization. Carrel and Gregory, reported that organizational productivity is contingent on various factors which embrace personal (motivation, job satisfaction, good health and safety and productivityoriented skills) and organizational climate (leadership styles, job security, Compensation design and management, condition of service, nature of work and workload.

Therefore, job satisfaction is essential within an organization if employees are not contented, the work they do performance, productivity, commitment along with the social associations among the management as well as their subordinates are usually decreased [18]. For example, in an organization where work performance isn't recognized through promotion and salary increases, productivity of employees is commonly lower. In an effort to satisfy the needs of employees, many managers make use of incentive programs, despite the fact that research has consistently confirmed that no amount of money will translate into sustainable levels of job satisfaction or motivation [26]. Fajana, In his work identified a long range of factors / combined to affect an individual's level of satisfaction. These include supervision or leadership (concern for people, task, and participation), job design (scope, depth, interest, perceived value).

\subsection{Demographics variables and job satisfaction (Gender, Age, Educational level)}

Relationship between job satisfaction and demographic variables of employees in an educational sector, Paul and Phua showed that while variables, for example, educational level and age affected the levels of job satisfaction, the variables: scholastic capability, sexual orientation, conjugal status, and length of job had no impact of measurable noteworthiness. Noordin and Jusoff found that the demographic components, for example, present place of employment status, conjugal status, age and compensation seem to have huge effect on the respondents' job satisfaction level.

In spite of the way that analysts have discovered various segments that relate to employee job satisfaction, all these four segments could be arranged into two general social affairs: (a) individual components, that concentrate on traits of individual and qualities and (b) biological variables, which need to do with components joined using the work itself or even the workplace., It was showed that the significance of demographic variables in recognizing the measure of job satisfaction, and along these lines, view environment and private components as noticeably fighting models, Olowokere, Jafar, 2006. Fields says that individual qualities, for example educational level, age, sex and don't lead incrementally to the change in work satisfaction that portrayed through the variables illuminating the errand situation. In like way, other scientist, like Ellickson and Logsdon found that demographic variables were by and large poor pointers of employee job satisfaction.

As indicated by Mehboob, Sarwar, \& Bhutto, female employees were more satisfied by their job than their male partners at the universities. Furthermore Castillo \& Cano found that contrasted with male employees, female lecturers were lesser fulfilled. Additionally, discoveries of Moguerou likewise reasoned that female individuals are less fulfilled than male individuals. Syed et al. found that female employees are more fulfilled contrasted and male employee. Crossman and Harris reported that guys were marginally more fulfilled than females.

Gender and job satisfaction has been broadly looked into. Be that as it may, the outcomes have been blended. Females express lower levels of job satisfaction than males [51]. Spector offered a few explanations behind this: (1) administrative/expert occupations are not liable to female, (2) they are more satisfied with less obligation and lower pay than men, and (3) they have lower assumptions about on the grounds that they contrast themselves or what they will get with other ladies who are in comparative circumstances. Be that as it may, a few studies reported no relationship at all in the middle of sex and general job satisfaction [42] [16]. The past perspective of men as the fundamental suppliers of family salary no more exists subsequent to the high average cost for basic items implies that men can never again be the main wellspring of monetary backing. As a result, it is imperative to inspect the relationship in the middle of gender and job satisfaction once again [41].

In any case, research discoveries have demonstrated that the job satisfaction of college employees from Uganda reported age to be a critical impact on showing satisfaction [52]. As indicated by DeVaney \& Chen more senior staff will probably be fulfilled than junior staff. So also Mello recognized that job satisfaction increase with age.

Another customary individual segment that has been inspected is educational level. Undoubtedly, research take a gander at the relationship between the level of education and job satisfaction has shown unmistakable revelations. A couple of investigators found a positive relationship between educational level and job satisfaction while others perceived a 
negative affiliation. Distinctive studies have demonstrated for all intents and purposes zero relationship in the middle of educational level and job commitment. A couple of studies have reported that associations between educational level and job commitment are sure, Okpara.

On the parts of employee job satisfaction or dissatisfaction the journey for an appreciation has been an advancing locale of excitement for managers and social researchers around the world for a great time. The employee job satisfaction speaks to a basic subject in an association and individual with interests stem from pros' conviction [51]. Whether in a negative or positive way authorities in the field have assessed a couple of variables that relate with job satisfaction. Then again, the noteworthiness of the diverse variables seems to change from the beginning with one situation then onto the following. Performing the same occupation with the individuals in the same environment does not determine the same level of satisfaction. The multi-edge highlight of employee job satisfaction gets the opportunity to be seen when endeavoring to center the estimations of employee's satisfaction. There is no uniform comprehension among researchers about the components that gives attention to job satisfaction, regardless of the way the authorities in the field recognize the parts that impact the level of job satisfaction [51]. A bigger number of measurements have been distinguished [3], While a few studies in this field are restricted to only a couple of dimensions or elements.

\section{Methodology}

Based on the extant literature of Duong and Ghafoor, a quantitative research approach is suggested and used in this study. The Minnesota satisfaction questionnaire (MSQ) created by Weiss \& Dawis, was utilized to gauge job satisfaction of lecturers. Simple random technique was used to select the respondents for the study. 217 questionnaires were administered manually to potential academics chosen from the universities, and 199 questionnaires were returned. The questionnaires yielded a response rate of $91.7 \%$. Based on Dillman and Malaney, a rate in between $30 \%$ to $60 \%$ is considered to be acceptable for analysis purposes in most research studies. Data was analyzed using SPSS.

\section{Results}

Objective No 1: Examine the differences between job satisfactions of the academicians based on gender.

Table 1. t-Test Results on Job Satisfaction of Academicians Based On Gender

\begin{tabular}{cllllll}
\hline $\begin{array}{l}\text { Variabl } \\
\text { e }\end{array}$ & $\begin{array}{l}\text { Gend } \\
\text { er }\end{array}$ & N & $\begin{array}{l}\text { Mea } \\
\text { n }\end{array}$ & SD & t & $\begin{array}{l}\text { p- } \\
\text { val } \\
\text { ue }\end{array}$ \\
\hline Mob & Male & 13 & 3.76 & .539 & & \\
$\begin{array}{c}\text { Jatisfacti } \\
\text { on }\end{array}$ & 2 & 37 & 38 & 1.32 & 0.18 \\
& Femal & 67 & 3.66 & .372 & & 5 \\
& e & & 60 & 55 & & \\
\hline \hline
\end{tabular}

Significance level, .05, df = 199

The results reveal independent sample t-test on job satisfaction on gender among lecturers in Nigerian universities. Findings show that there was no significant difference in the job satisfaction level between male and female lecturers. $(\mathrm{t}(199)=.185, \mathrm{p}$ $>$.05). The mean scores indicate that the job satisfaction level of male lecturers $(\mathrm{M}=3.7637, \mathrm{SD}=$ $0.53938)$ and female lecturers $(\mathrm{M}=3.6660, \mathrm{SD}=$ $0.37255)$ are more or less the same. Therefore, the research fails to reject Ho, which says that there is no significant difference between job satisfaction among male and female lecturers in the Nigeria universities.

Objective No 2: Examine the difference between job satisfactions of the academicians based on age.

Table 2. One-way ANOVA Results on Job Satisfaction Based on Educational Background

\begin{tabular}{lllllll}
\hline \hline Variable & $\begin{array}{l}\text { Qualific } \\
\text { ation }\end{array}$ & N & Mean & SD & F & $\begin{array}{l}\text { Si } \\
\text { g- } \\
\text { t }\end{array}$ \\
\hline Job & Bachelo & 199 & 3.784 & 0.415 & & \\
satisfacti & Masters & 199 & 3.689 & 0.461 & 0.66 & 0. \\
on & & & 7 & 30 & 1 & 51 \\
& Ph.d & 199 & 3.737 & 0.554 & & 7 \\
& & & 0 & 18 & & \\
\hline \hline
\end{tabular}

The table displays the ANOVA results that show there is no significance difference between job satisfaction and educational qualification among the lecturers in Nigerian universities. The mean scores of bachelor, master and doctorate lecturer is as follows $(\mathrm{M}=3.7844, \mathrm{M}=3.6897$ and $\mathrm{M}=3.7370$ 
respectively) on their various job satisfaction in the university. The ANOVA test showed that there was no significant differences in the mean (sig-t $>.05$ ) for job satisfaction among bachelor, master and $\mathrm{PhD}$ lecturers $(\mathrm{F}(0.661),=0.517>.05)$. The findings show that academicians with bachelor, master and $\mathrm{PhD}$ show no significance difference in their job satisfaction.

Objective No 3: Examine the difference between job satisfactions of the academicians based on age.

The table presents the analysis done to determine the differences by age on lecturer's job satisfaction.
The analysis of variance or ANOVA shows no significant differences between the mean values of the groups of age of the lecturers. The means scores of the groups of the ages is as follows $(\mathrm{M}=1.83$, $\mathrm{M}=1.80, \mathrm{M}=2.04, \mathrm{M}=2.11, \mathrm{M}=2.36$ and $\mathrm{M}=1.96$ ) respectively on their job satisfaction. The analysis shows no significant as sig $>0.05$. For job satisfaction among the age group $(\mathrm{F}(1.732)=.129>0.05$. Therefore, we fail to reject $\mathrm{H}_{0}$, which say that there are no significant differences.

Table 3. One-way ANOVA Results on Job Satisfaction Based on Age

\begin{tabular}{|c|c|c|c|c|c|c|c|c|c|c|}
\hline Variable & $\begin{array}{l}\text { Age } \\
\text { group }\end{array}$ & $\mathbf{N}$ & $\mathbf{M}$ & SD & Source & $\begin{array}{l}\text { Sum of } \\
\text { squares }\end{array}$ & df & $\begin{array}{l}\text { Mean } \\
\text { square }\end{array}$ & $\mathbf{F}$ & Sig t \\
\hline \multirow{7}{*}{$\begin{array}{l}\text { Job } \\
\text { satisfaction }\end{array}$} & $26-30$ & 40 & 1.83 & 0.747 & & & & & \multirow{7}{*}{1.732} & \multirow{7}{*}{.129} \\
\hline & $31-35$ & 35 & 1.80 & 0.868 & & & & & & \\
\hline & $36-40$ & 46 & 2.04 & 0.698 & $\begin{array}{l}\text { Between } \\
\text { group }\end{array}$ & 4.344 & 5 & .869 & & \\
\hline & $41-45$ & 39 & 1.95 & 0.647 & & & & & & \\
\hline & $46-50$ & 28 & 2.11 & 0.786 & $\begin{array}{l}\text { Within } \\
\text { group }\end{array}$ & 108.410 & 193 & .562 & & \\
\hline & $51-55$ & 11 & 2.36 & 0.809 & & & & & & \\
\hline & Total & 199 & 1.96 & 0.755 & Total & 112.754 & 198 & & & \\
\hline
\end{tabular}

\section{Discussion of findings}

This study was to decide mean contrasts between gender, age and educational level. In light of past discoveries, demographic elements have huge consequences for job satisfaction [51]. On the other hand, Spector states that although demographic variable has been appeared to have an association with job satisfaction the reasons are not all around outlined. Subsequently, research is obviously expected to figure out whether identity attributes (age, sex and educational level) identify with job satisfaction [51]. The discoveries of the present study demonstrated that diverse demographic variables have distinctive recognition towards job satisfaction.

As far as gender, a few studies showed an inconsistency in gender and job satisfaction. The discoveries of the present study demonstrated no critical distinction in the job satisfaction level between the men and women lecturers. These discoveries agreed with the works of Oshagbemi, and [16] which additionally bolster the discoveries that there is no noteworthy relationship between gender and job satisfaction.
Regardless of a few discoveries that, as talked about prior, it was found that there are no distinctions in job satisfaction among men and ladies, a more in-depth and out investigation of the components that constitute job satisfaction uncovers contrasts in the effect that they have on the level of job satisfaction as indicated by gender [46]. The frequencies on gender showed that the larger part of academicians $(66.3 \%)$ were male and just $(32.2 \%)$ were female lecturers in Nigerian universities. The clarification for this is men assume a key part in the work environment, while ladies assume a key part in their homes and their energy is not prevalent in the work environments.

Regarding age gather, the discoveries of this study demonstrate that there is no noteworthy contrast between the age group of the lecturers and job satisfaction. These discoveries were upheld by [38], Studies in view of the life cycles and work stages propose that determinants of job satisfaction change contingent upon the specific phase of the profession. 
Another conceivable clarification is that older group has a greater degree of job satisfaction of their job. It can likewise be that lecturers who are in 51 years age or more have indicated more satisfaction, this was seen from the consequence of the Mean, which is $\mathrm{M}=2.36$, demonstrating the most astounding from the other age bunch. Another vital issue is that more youthful and older lecturer's perspective to work and self fundamentally in distinctive ways. Accordingly, the higher the lecturers age the lower the potential outcomes of leaving the universities.

For educational qualification, information demonstrated no huge contrasts among the three groups (bachelor, master and $\mathrm{PhD}$ ) and lecturer's job satisfaction. A few analysts discovered a positive relationship between educational qualification and job satisfaction while others distinguished a negative association. Different studies have demonstrated next to zero relationship in the educational level and job satisfaction. Then again, the discoveries of different studies have been that no huge relationship exists between job satisfaction and educational qualification, which bolster the present studies, for instance, [12] and [49] studies bolster this study. Taking everything into account, educational institution, for example, colleges and schools has teaching staffs that are fulfilled by their occupation. All together words the essentialness of every single educational institution lies in the ability of lecturers to add to the advancement of their associations [25]. In the event that lectures are fulfilled by their occupation, it will convey all round advancements to the universities in Nigeria.

\section{Conclusion}

This study was proposed to research the relationship between demographic variables and job satisfaction among academicians in Nigerian public universities. The essential concern was to investigate the relationship between chose academicians on their job satisfaction in connection to the demographic variable, which have not managed in former studies in Nigerian public universities. The study yields a few essential results and adds to the fillings an exact and theoretical crevice in the organizational writing broadly and universally. In view of the discoveries, the accompanying conclusions have been drawn.

It was reasoned that there is no significance distinction between the age group of lecturers and their job satisfaction. It was found from the discoveries that the lecturers between the age bunches 36-40 yrs are most age group found in the universities, which demonstrates that more youth are being utilized in the educational settings in Nigeria. With the standards of catch them youthful. This shows lecturers within $36-40 y r s$ had a slant to stay in their colleges than the other age bunch.

From the discoveries it was found that there was no huge relationship between educational qualification and job satisfaction. The study demonstrated that lecturers with master's holders are more in the university than other degree holders, which shows that the minimum qualification for entering into a lecturing job in Nigeria universities is master's holders. There was no gender wise significant difference regarding job satisfaction of the lecturers in Nigerian universities. While male lecturers had higher mean scores, which demonstrates that men are more process arranged and thinks more about how objectives are accomplished not just that they are accomplished.

This study gave the establishments to future exploration to expand the comprehension in the parts of demographic variables and academicians job satisfaction. Replication of this study with different samples of academicians from different regions and colleges in Nigeria to affirm the aftereffects of this study or recognize variables of job satisfaction are suggested.

The discoveries of this study, makes a vital commitment to our comprehension of academicians' job satisfaction in tertiary institution. It is trusted that the outcomes will animate further research concerning other just as imperative angles influencing worker relations. This study was confined to one build of business related practices of job satisfaction, henceforth further research in the zone could stretch out to cover different develops which additionally identify with worker authoritative adequacy and results.

\section{References}

[1] Abdulla, J., Djebarni, R., \& Thomas, B. (2008). Construction of a scale measuring the job satisfaction of public sector employees in the UAE with particular reference to the Dubai Police Force. Paper presented at the Saudi International Innovation Conference, UK.

[2] Adedeji, K. O. (2002). Influence of workers' job satisfaction on productivity in manufacturing industries. journal of Management Development,, 4(2), 64- 73.

[3] Adeyemo, B. L. (2006). Secondary School teachers level of job satisfaction and conditions of service in Ikere Ekiti local Government Area of Ekiti State. Unpublished B. Ed. Projec. University of Ado-Ekiti.

[4] Akpofure, R.-R., Ikhifa, O. G., Imide, O. I., \& Okokoyo, I. E. (2006). Job Satisfaction Among Educators in Colleges of Education in Southern Nigeria. Journal of Applied Sciences, 6(5), 1094-1098. 
[5] Awang, A., Asghar, A., \& Subari, K. A. ( 2010). Entrepreneurial orientation among Bumiputera Small and Medium Agro-Based Enterprises (BSMAEs) in West Malaysia: Policy implication in Malaysia. Int $\mathbf{J}$ of Bus and Manag, 5(5), 13 - 143.

[6] Babajide, P. H. (2001). Analysis of work place attitude and behaviour; A Case study of Nigerian Breweries Plc. Unpublished MSC Project. University of Ibadan, Ibadan

[7] Castillo, J. X., \& Cano, J. (2004). Factors Explaining Job Satisfaction Among Faculty. Journal of Agricultural Education, 45(3), 72.

[8] Clark, A. E., \& Oswald, A. J. (1994). Unhappiness and unemployment. Economic Journal, 104, 648-659.

[9] Clovin, L. A. (2001). Analysis of factors influencing teachers' morale Questionnaire. Journal of Educational Management,, 12(11), 122-131.

[10] Chimanikire, P. M., Gadzirayi, C. T., Muzondo, N., \& Mutandwa, B. (2007). Factors affecting job satisfaction among academic professionals in tertiary institutions in Zimbabwe. African Journal of Business Management, 16(2), 166-175.

[11] Crossman, A., \& Abou-Zaki, B. (2003). Job satisfaction and employee performance of Lebanese banking staff. Journal of Managerial Psychology,, 18(4), 368-376.

[12] Crossman, A., \& Harris, P. (2006). Job satisfaction of secondary school teachers. Educational Management, Administration and Leadership, 34(1), 29-46.

[13] Daft, R. L., \& Marcic, D. (2006). Understanding Management. Thomson South-Western Mason, OH.

[14] DeVaney, S. A., \& Chen, Z. S. (2003a). Job Satisfaction of recent graduates in Financial services, US Department of Labour. Bureau of Labour Statistics Compensation and Working Conditions Online.

[15] Diaz- Serrano, L., \& Cabral, V. J. A. (2005). Low pay, higher pay and job Satisfaction within the European union empirical evidence from fourteen countries. Paper presented at the IZA Discussion paper, Institute for the study of labour (IZA).

[16] Donohue, S., \& Heywood, J. (2004). Job satisfaction, comparison income and gender:evidence from the NLSY. International Journal of Manpower, 25, , 211-234.

[17] Ellickson, M., \& Logsdon, K. (2002). Determinants of job satisfaction of municipal government employees. State Local Government Review, 31(3), 343-358.

[18] Fajana, S. (1996). Organizational Policies and Human Behaviour in Trade Unions
[19] Fajana, S. (2002). Human Resource Management: An Introduction. Lagos: Labofin and Company.

[20] Fields, D. ( 2002). Taking the Measure of Work: A Guide to Validated Scales for Organizational Research and Diagnosis. Sage Publications.

[21] Hersey, P., Blanchard, K. H., \& Johnson, D. E. (2001). Management of Organizational Behavior: Leading Human Resources. New Jersey:: Prentice-Hall, Inc.

[22] Jaafar, M., Ramayah, T., \& Zainal, Z. (2006). Work Satisfaction and Work Performance.

[23] Janssen, O., \& Yperen, N. W. (2001). Employees' goal orientations, the quality of Leader-member exchange, and the outcomes of job Performance and job satisfaction. Academy of Management Journal,, 47(3), 368-384.

[24] Johnson, M. (2000). Managing in the Next Millennium. Oxford: Butterworth-Heinemann.

[25] Joolideh, F., \& Yeshodhara, K. (2008). Organizational commitment among high school teachers of India and Iran. Journal of Educational Administration 47(1), 127-136.

[26] Joyce, W. F., \& Slocum, J. W. (2004). Collective climate: Agreement as a basis for defining aggregate climates in organizations. Academy of Management Journal, 27(6), 721-742.

[27] Gaziouglu, F., \& Tansel, A. (2002). Job Satisfaction in Britain: Individual and Job related factors. Paper presented at the Economic research centre working papers in economic.

[28] Locke, E. A. (1976). The Nature and Causes of Job Satisfaction: Handbook of Industrial and organizational Psychology.

[29] Mehboob, F., Sarwar, M. A., \& Bhutto, N. A. (2012). Factors affecting job satisfaction among faculty member. Asian Journal of Business and Management Sciences, 1(12), 1-9.

[30] Mello, J. (2006). Strategic Human Resources Management. Ohio: Thompson South Western.

[31] Moguerou, P. (2002). Job satisfaction among US Ph.D. graduates: the effects of gender and employment sector. mimeo University de Bourgogne.

[32] Mullins, L. J. (2005). Management and organizational Behaviour. New Jersey Prentice Hall.

[33] Narimawati, S. E. (2007). The Influence of Work Satisfaction, Organizational Commitment and Turnover Intention Towards the Performance of Lecturers at West Java's Private Higher Education Institution. Journal of Applied Sciences Research, 3(7), 549 - 557. 
[34] Noordin, F., \& Jusoff, K. (2009). Levels of job satisfaction amongst Malaysian academic staff. Asian Social Science, 5(5), 122-128.

[35] Odanye, C. E. (2004). Relationship between workers' improved morale and organizations performance. Journal of Personnel Administration, 5(2), 14-22.

[36] Olaoye, A. K. (2003). Training and development strategies in work organizations. Journal of Transport Management, 3, 33-41.

[37] Olowokere, E. (2002). A study of Job dissatisfaction patterns of secondary school teachers in Oyo state. University of Ibadan, Ibadan. Unpublished M.Ed. Dissertation.

[38] Okpara, J. O. (2004). Personal characteristics as predictors of job satisfaction: An exploratory study of IT managers in a developing economy. Information Technology \& People, 17(3), 327-338.

[39] OK Sakiru, et al, (2014). Relationship between head of department leadership styles and lecturers job satisfactions in Nigerian public Universities. Asian Social Science; Vol. 10, No. 6; 2014

[40] Oshagbemi, T., \& Gill, R. (2000). Gender differences in the job satisfaction of university teachers. Women in Management Review, 15(7), 331-343.

[41] Oshagbemi, T. (2003). Personal correlates of job satisfaction: empirical evidence from UK universities. International Journal of Social Economics, 30(12), 12101232.

[42] Oshagbemi, T., \& Gill, R. (2004). Differences in leadership styles and behaviour across hierarchical levels in UK organisations. Leadership \& Organization Development Journal, 25(1), 93-106.

[43] Paul, E. P., \& Phua, S. K. (2011). Lecturers' job satisfaction in a public tertiary institution in Singapore: ambivalent and non-ambivalent relationships between job satisfaction and demographic variables. Journal of Higher Education Policy and Management, 33(2), 141-151.

[44] Raiz, S. S., \& Haider, O. (2000). Transformational leadership, organizational commitment relations between transformational leadership and work outcomes. Journal of Occupational Review, 21(1), 1-36.

[45] Robins, S. P. (2001). Organizational Behaviour, new jessey Prentice Hall. Weiss, D.J., Dawis, R.V., England, G.W., \& Lofquist, L.H., (1967). Manual for Minnestota Satisfaction Questionnaire. Minnesota Statues in Vocational rehabilitation, 22.

[46] Robbins, S. P., Odendaal, A., \& Roodt. (2003). Organizational Behavior. Cape Town: Pearson Education.
[48] Santhapparaj, A. S., \& Alam, S. S. (2005). Job Satisfaction Among Academic Staff in Private Universities in Malaysia. . Journal of Social Science, 1(2), 72-76.

[49] Scott, M., Swortzel, K. A., \& Taylor, W. N. (2005). The relationships between Selected demographic factors and the level of job satisfaction of extension agents". Journal of Southern Agricultural Education Research, 55(1), 102-115.

[50] Smith, G. L, Wilber, Shashi, K., Gupta, P., \& Stackhouse. (2002). Surface Radiation Budget and Climate Classification. Journal of Climate, 15, 1175-1188.

[51] Spector, P. (2008). Industrial and organizational psychology: Research and practice. New York: John Wiley \& Sons.

[52] Sseganga, K., \& Garrett, R. M. (2005). Job satisfaction of university academics: Perspectives from Uganda. Higher Education, 50, 33-56.

[53] Syed, A. A. S. G., Nadeem, B., Sabir, M., Faiz, M., Shaikh, \& Hina, S. (2012). Job Satisfaction of Faculty Members of Universities in Pakistan: A Case Study of University of Sindh-Jamshoro. Modern Applied Science, 6(7).

[54] Suzanne, R. M., Claudius, F. E., \& Patricia, V. O. (2010). Determinants of organizational performance and efficiency at workplace. Journal of Applied Psychology.

[55] Ting, Y. (1997). Determinants of job satisfaction of federal government employees. Public Personnel Management, 26(3), 313-334.

[56] Zaccaro, S. J., \& Klimoski, R. . (2001). The nature of organizational leadership: understanding the performance imperatives confronting today's leaders. San Francisco: Jossey-Bass. 